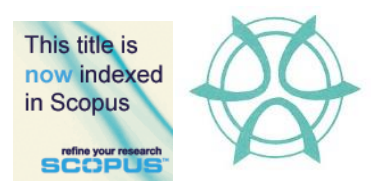

PLANNING MALAYSIA:

Journal of the Malaysian Institute of Planners

VOLUME 16 ISSUE 3 (2018) Page 297 - 307

\title{
MULTI-DIMENSIONAL HUMAN INTERACTION IN OPEN SPACES
}

\author{
Filzani Illia Ibrahim ${ }^{1}$, Dasimah Omar $^{2} \&$ Nik Hanita Nik Mohamad \\ ${ }^{I}$ School of Architecture, Building and Design \\ TAYLORS UNIVERSITY LAKESIDE CAMPUS, MALAYSIA \\ ${ }^{2,3}$ Faculty of Architecture, Planning \& Surveying \\ UNIVERSITI TEKNOLOGI MARA, MALAYSIA
}

\begin{abstract}
Due to rapid urban development, open spaces have changed drastically over the decades and generations have been struggling with its consequences. There have been various studies on how open spaces provide positive reaction to human. Apparently, in relation to open spaces, Malaysia has received very little attention from researchers. This paper investigates the human interaction experienced in the open spaces and how it relates to city sustainability. The aim of this paper is to provide valuable insight of the various dimensions of human interaction experienced in open spaces. This study employed a quantitative research method whereby questionnaire survey was administered to 861 respondents who visited five selected open spaces of Shah Alam, Selangor, Malaysia. The findings in this paper address human-human interaction and human-nature interaction in the parks.
\end{abstract}

Keywords: open spaces, human-human interaction, human-nature interaction 
Filzani Illia Ibrahim, Dasimah Omar \& Nik Hanita Nik Mohamad

Multi-Dimensional Human Interaction in Open Spaces

\section{INTRODUCTION}

Currently open spaces are emerging as one of the most important spaces in the urban fabric. They are multi-purpose public spaces in the city that offer social, economic, and environmental benefits. They help to enhance the image of the city, and improve the quality of urban life. Hence, there are various theories that relate to the multi-dimensional human interaction in the open spaces. Chiesura (2004) claimed that the major function of open space is to satisfy people's recreational need. However it can be seen that open spaces provide more than just recreational satisfaction. Arifin (2005) stated that open spaces with plant represent natural contact with human due to their roles in producing oxygen, and controlling the surrounding system and the soil water. Moreover, natural landscape in open spaces can sometimes play a key role in promoting social interaction (Oguz, 2000). Hence, open spaces might have different usage and purposes towards different people in the urban areas.

As there are various studies on how open spaces provide positive reaction to human and nature, hence the question is multi-dimensional human interaction in different hierarchy of open spaces offer different positive impacts to the urban dwellers? Multi-dimensional human interaction in the open spaces can be categorised as human-human interaction and human-nature interaction. Under the human-human interaction, there are three variables that can be measured which are social interaction, citizen participation and sense of community. As for the human-nature interaction, the variables to be measured are contact with nature, aesthetic preference, and recreational or play. Thus, among these variables, which are the variables that are suitable for each types of open spaces.

According to Mutiara \& Isami, (2012) people's involvement and interaction in open spaces can enhance the sense of belonging among people and at the same time increase the degree of neighbourhood attachment. However, different hierarchy of open spaces might offer different purposes and interactions among the users. The typology of open spaces are basically characterized by population number, size of the open space and also the facilities provided in the open space.

\section{HUMAN INTERACTION IN OPEN SPACES}

Although open spaces play vital role in improving the environmental system (Marzukhi, Karim, \& Latfi, 2012; Ariffin, 2005), their main function is to satisfy people's recreational need. When an open space was designed, the overarching consideration was based on real or perceived notions of recreational needs.

Increasing empirical evidence have indicated that the presence of natural assets and it components in urban context provide significant contribution to the quality of life in many ways. Besides vital environment services such as air and water purification, and wind and noise filtering, open spaces provide social and psychological services which are of crucial significance for the liveability of 
PLANNING MALAYSIA

Journal of the Malaysia Institute of Planners (2018)

modern cities and the well-being of urban dwellers (Chiesura, 2004). They help in reducing stress, rejuvenate city dwellers and provide a sense of tranquillity (Kaplan, 1993). Conway (2000) verified beliefs about stress reduction benefits and mental health through the experience on the use of open spaces.

Hence, Matsuoka and Kaplan (2008) provided a valuable insight into how human interact with outdoor urban environments, which included open spaces. They provided major themes, or purpose of using open spaces, that are directly linked with open spaces which are; human-nature interaction and humanhuman interaction. As for the nature needs, there are three variables that can be measured which are, contact with nature, aesthetic preference, and recreation or play. Whereby for human needs, the variable to be measured are social interaction, citizen participation, and sense of community. There are much to be learned about the relationship among the six human interactions examined by the researchers. Hence, with the rapid urbanization in the city, it is important to study the issues of scale in terms of human benefit. Moreover, Matsuoka and Kaplan (2008) stated that the human needs that are categorized into six general themes and that these needs often interact with each other. Hence, giving an urban setting, especially open spaces might affect the fulfilment of other purposes.

\section{RESEARCH METHODOLOGY}

This research takes the view of Sekaran and Bougie (2016) in selecting structured questionnaire surveys to investigate and measure attitudes and perceptions. It is considered the most appropriate method to obtain a large amount of data as it permits analysis in statistical form within a relatively short of time. Hence, in this study, questionnaire survey was carried out to gather the data, namely the user's profile of open spaces (D1); the human-human interaction in open spaces (D2); the human-nature interaction in open spaces (D3); and the perceived benefits and vitality of open spaces (D4).

The results served very well in formulating the variables and items for four domains in the research instrument of questionnaire survey. There were six parts in the questionnaire form, namely: (1) socio demographic profile; (2) purpose and visit information; (3) human-nature interaction; (4) human-human interaction; (5) facilities, amenities and accessibilities; and (6) perceived benefits and opinion.

Sampling was determined based on Sekaran and Bougie's (2016) rules in determining sample size namely: (1) sample size larger than 30 and less than 500 are appropriate for most research and (2) where sample are to be broken into subsamples, a minimum sample size of 30 for each category is necessary. Thus, this study uses a disproportionate stratified random sampling where the samples size was ascertained according to the size ratio of each park in relation to the total size of study area (Table 1). 
Filzani Illia Ibrahim, Dasimah Omar \& Nik Hanita Nik Mohamad

Multi-Dimensional Human Interaction in Open Spaces

Table 1: Sample size for each study area

\begin{tabular}{llll}
\hline Study Area & Typology & Sample Size & $\%$ \\
\hline Taman Tasik Shah Alam & Urban Park & 428 & 49.7 \\
Section 7 & Local Park & 149 & 17.3 \\
Section 18 & Neighbourhood Park & 134 & 15.6 \\
Section 8 & Playing Field & 100 & 11.6 \\
Section 4 & Playground & 50 & 5.8 \\
\hline TOTAL & & 861 & 100 \\
\hline
\end{tabular}

The questionnaire survey was administered to 861 respondents who visited the five selected open spaces of Shah Alam, Selangor, Malaysia. The response rate for the questionnaire survey was 100 percent.

\section{RESULTS AND FINDINGS}

The data from survey questionnaires was coded into SPSS software for statistical analysis. The main focus of the analysis was to understand the relationship of human-human interactions and human-nature interactions that took place in the open spaces area. In terms of users' profile, it was found that majority of the respondents visited the open spaces more than three times and mostly during the weekend. Additionally, the findings show that majority of the respondents visited the open spaces in the afternoon and spent between 30 minutes to 60 minutes in the parks. Majority of the respondents visited the open spaces accompanied by a partner or friends. Hence, these provide great optimism that improved social interactions can be promoted through a properly design open spaces.

\section{Human Interaction}

To measure the human interaction that respondents experienced in the open spaces, the structure of the questionnaire was divided into three sections that are contact with nature, aesthetic preference and recreational play. The data was then analysed in SPSS using Chi-square and p-value methods. Table 2 below shows the overall analysis of human-nature interaction.

Table 2: Overall analysis of human interaction

\begin{tabular}{|c|c|c|c|c|c|c|}
\hline \multicolumn{7}{|c|}{ Contact with Nature Domain } \\
\hline & & $\begin{array}{l}\text { Neighbourhood } \\
\text { park }\end{array}$ & Playfield & $\begin{array}{l}\text { Local } \\
\text { park }\end{array}$ & Playground & $\begin{array}{l}\text { Urban } \\
\text { park }\end{array}$ \\
\hline UN1 & Unity with nature & 0.0126 & 0.3443 & 0.1783 & 0.1569 & 0.2440 \\
\hline US1 & Unity with my self & 0.2048 & 0.0731 & 0.0765 & 0.7860 & 0.1802 \\
\hline FR1 & Freedom & 0.0024 & 0.0569 & 0.1990 & 0.7138 & 0.2356 \\
\hline RS1 & Recreational Satisfaction & 0.6356 & 0.0985 & 0.0412 & 0.7886 & 0.1726 \\
\hline AD1 & Adventure & 0.1728 & 0.3911 & 0.0095 & 0.0588 & 0.7030 \\
\hline HP1 & Happiness & 0.4380 & 0.0779 & 0.0306 & 0.6805 & 0.3928 \\
\hline VO1 & Vitality & 0.4594 & 0.0055 & 0.2102 & 0.2295 & 0.6561 \\
\hline \multicolumn{7}{|c|}{ Aesthetic Preference Domain } \\
\hline UN2 & Unity with nature & 0.1369 & 0.6109 & 0.0807 & 0.7747 & 0.9044 \\
\hline US2 & Unity with my self & 0.0377 & 0.7310 & 0.0155 & 0.8888 & 0.1004 \\
\hline FR2 & Freedom & 0.1750 & 0.8179 & 0.0254 & 0.2529 & 0.1971 \\
\hline RS2 & Recreational Satisfaction & 0.1125 & 0.5780 & 0.0050 & 0.5740 & 0.2315 \\
\hline
\end{tabular}


PLANNING MALAYSIA

Journal of the Malaysia Institute of Planners (2018)

\begin{tabular}{|c|c|c|c|c|c|c|}
\hline $\mathrm{AD} 2$ & Adventure & 0.3463 & 0.2680 & 0.0007 & 0.7260 & 0.8400 \\
\hline HP2 & Happiness & 0.0267 & 0.5099 & 0.0107 & 0.3293 & 0.8873 \\
\hline $\mathrm{VO} 2$ & Vitality & 0.7971 & 0.6512 & 0.2499 & 0.6006 & 0.6193 \\
\hline \multicolumn{7}{|c|}{ Recreation and Play Domain } \\
\hline $\mathrm{UN} 3$ & Unity with nature & 0.4405 & 0.1579 & 0.0002 & 0.2953 & 0.0091 \\
\hline US3 & Unity with my self & 0.5530 & 0.0857 & 0.0197 & 0.1181 & 0.0087 \\
\hline FR3 & Freedom & 0.6048 & 0.0886 & 0.0028 & 0.2575 & 0.0649 \\
\hline RS3 & Recreational Satisfaction & 0.9955 & 0.0492 & 0.0001 & 0.3626 & 0.0351 \\
\hline AD3 & Adventure & 0.6145 & 0.6607 & 0.0035 & 0.1913 & 0.1434 \\
\hline HP3 & Happiness & 0.4991 & 0.1774 & 0.0000 & 0.6294 & 0.0634 \\
\hline VO3 & Vitality & 0.4553 & 0.0605 & 0.0001 & 0.1197 & 0.1779 \\
\hline \multicolumn{7}{|c|}{ Social Interaction Domain } \\
\hline UN4 & Unity with nature & 0.1277 & 0.2097 & 0.6241 & 0.0149 & 0.0084 \\
\hline US4 & Unity with my self & 0.2179 & 0.6136 & 0.6973 & 0.4781 & 0.0117 \\
\hline FR4 & Freedom & 0.1658 & 0.6695 & 0.6568 & 0.4208 & 0.2127 \\
\hline RS4 & Recreational Satisfaction & 0.4434 & 0.0908 & 0.8026 & 0.7859 & 0.1018 \\
\hline AD4 & Adventure & 0.2254 & 0.4801 & 0.8822 & 0.2625 & 0.2125 \\
\hline HP4 & Happiness & 0.0373 & 0.7493 & 0.7761 & 0.7512 & 0.0286 \\
\hline $\mathrm{VO} 4$ & Vitality & 0.1206 & 0.4831 & 0.5874 & 0.1931 & 0.1395 \\
\hline \multicolumn{7}{|c|}{ Citizen Participation Domain } \\
\hline UN5 & Unity with nature & 0.7147 & 0.9540 & 0.0893 & 0.1569 & 0.0176 \\
\hline US5 & Unity with my self & 0.7712 & 0.0993 & 0.0977 & 0.3442 & 0.0089 \\
\hline FR5 & Freedom & 0.4831 & 0.9287 & 0.1303 & 0.5347 & 0.0018 \\
\hline RS5 & Recreational Satisfaction & 0.2674 & 0.3303 & 0.8605 & 0.7886 & 0.0006 \\
\hline AD5 & Adventure & 0.9455 & 0.8981 & 0.5659 & 0.5487 & 0.0529 \\
\hline HP5 & Happiness & 0.6462 & 0.2857 & 0.1068 & 0.8503 & 0.0056 \\
\hline VO5 & Vitality & 0.0864 & 0.0881 & 0.0868 & 0.8793 & 0.0023 \\
\hline \multicolumn{7}{|c|}{ Sense of Community Domain } \\
\hline UN6 & Unity with nature & 0.4535 & 0.0099 & 0.0826 & 0.0124 & 0.2132 \\
\hline US6 & Unity with my self & 0.2936 & 0.0044 & 0.1102 & 0.8888 & 0.4400 \\
\hline FR6 & Freedom & 0.1800 & 0.8179 & 0.1609 & 0.7361 & 0.1796 \\
\hline RS6 & Recreational Satisfaction & 0.0385 & 0.5780 & 0.3750 & 0.3941 & 0.0803 \\
\hline AD6 & Adventure & 0.9776 & 0.6757 & 0.1932 & 0.0016 & 0.0882 \\
\hline HP6 & Happiness & 0.8554 & 0.5380 & 0.0831 & 0.6688 & 0.2955 \\
\hline VO6 & Vitality. & 0.5434 & 0.6512 & 0.0573 & 0.6006 & 0.6786 \\
\hline
\end{tabular}

The results in Table 1 show that the main purpose of respondents visiting open spaces is for recreational and play. Thus, it can be stated that the main purpose of urban dwellers using the open spaces is for recreational purposes. This is supported by Marzukhi, Karim and Latfi (2012), whom stated that the provision of open spaces should have positive impact on the quality of public life and public health which then link to the economic and social aspects of the urban dwellers.

From the overall analysis it can also be seen that the main purpose of urban dwellers needing open spaces in the city they lived in is due to enjoy recreational satisfaction, unity with self, sense of freedom, adventure and happiness. There were only a few of the respondents agreed that the open spaces act as a positive channel to unite with nature. This is supported by Mansor, Said and Mohamad (2010), who emphasised on the lack of knowledge on the relationship of open spaces in promoting beneficial well-being effects and nature to the urban residents. However, the positive attitudes (measured by satisfaction level towards unity with nature, unity with self, freedom, recreational satisfaction, adventure, and happiness) of urban dwellers are commonly found while they are utilising the open spaces. 
Filzani Illia Ibrahim, Dasimah Omar \& Nik Hanita Nik Mohamad

Multi-Dimensional Human Interaction in Open Spaces

As for the relationship of the city sustainability and the purpose of open spaces for the urban dwellers, from the overall findings it can be seen that city sustainability relates to the domain of contact with nature, recreational and play, and citizen participation. Kim (2005) suggested that more and more research and investment on open spaces might create prosperous, liveable and equitable cities in developing countries. Thus, more open spaces should serve not only for the contact with nature, citizen participation and recreational activities but also towards the aesthetic preference, social interaction and sense of community. Hence, from the exploratory survey and behaviour mapping conducted suggest that the human-human interaction in open space domain can be divided into three which are social interaction, citizen participation and sense of community. Table 3 shows the overall findings on social interaction in the open spaces.

Table 3: Overall findings on human-human interaction in open spaces

\begin{tabular}{|c|c|c|c|c|c|c|}
\hline \multicolumn{7}{|c|}{ Social Interaction Domain } \\
\hline & & $\begin{array}{l}\text { Neighbourhood } \\
\text { park }\end{array}$ & Playfield & $\begin{array}{l}\text { Local } \\
\text { park }\end{array}$ & Playground & $\begin{array}{l}\text { Urban } \\
\text { park }\end{array}$ \\
\hline SI1 & $\begin{array}{l}\text { I always come here for social } \\
\text { interaction with my friends }\end{array}$ & 0.1763 & 0.6577 & 0.6617 & 0.1989 & 0.2076 \\
\hline SI2 & $\begin{array}{l}\text { The open space is a suitable place for } \\
\text { social interaction }\end{array}$ & 0.4501 & 0.3012 & 0.6515 & 0.0899 & 0.4986 \\
\hline SI3 & $\begin{array}{l}\text { I can pursue many social activities in } \\
\text { this open space }\end{array}$ & 0.9208 & 0.6839 & 0.6287 & 0.6912 & 0.4410 \\
\hline SI4 & $\begin{array}{l}\text { I feel happy doing social interaction } \\
\text { in this open space }\end{array}$ & 0.0065 & 0.2708 & 0.5198 & 0.6563 & 0.7036 \\
\hline SI5 & $\begin{array}{l}\text { The design of the open space allow } \\
\text { me to have social interaction easily } \\
\text { with my friends }\end{array}$ & 0.4104 & 0.0192 & 0.6784 & 0.6441 & 0.8017 \\
\hline SI6 & $\begin{array}{l}\text { Overall, I would rate the open space } \\
\text { with social interaction activities as } \\
\text { very satisfying }\end{array}$ & 0.1585 & 0.0054 & 0.7232 & 0.4377 & 0.6679 \\
\hline \multicolumn{7}{|c|}{ Citizen Participation Domain } \\
\hline $\mathrm{CP} 1$ & $\begin{array}{l}\text { The open space allows me to socialize } \\
\text { with other citizen }\end{array}$ & 0.5512 & 0.1333 & 0.9863 & 0.2410 & 0.3157 \\
\hline $\mathrm{CP} 2$ & $\begin{array}{l}\text { The open space is suitable for citizen } \\
\text { participation in the community }\end{array}$ & 0.7787 & 0.9260 & 0.7129 & 0.3910 & 0.9153 \\
\hline $\mathrm{CP} 3$ & $\begin{array}{l}\text { The open space strengthen the citizen } \\
\text { participation regardless activities and } \\
\text { events held here }\end{array}$ & 0.3722 & 0.8807 & 0.7789 & 0.7405 & 0.0498 \\
\hline $\mathrm{CP} 4$ & $\begin{array}{l}\text { The citizens here concern on what is } \\
\text { happening in the open space area }\end{array}$ & 0.5657 & 0.8085 & 0.9242 & 0.7693 & 0.0291 \\
\hline CP5 & $\begin{array}{l}\text { Overall, I would rate the citizen } \\
\text { participation in this open space as } \\
\text { very satisfying. }\end{array}$ & 0.3599 & 0.7262 & 0.5009 & 0.8517 & 0.1701 \\
\hline \multicolumn{7}{|c|}{ Sense of Community Domain } \\
\hline $\mathrm{SC} 1$ & $\begin{array}{l}\text { The open space allows me to have } \\
\text { community events }\end{array}$ & 0.5304 & 0.2592 & 0.1941 & 0.7157 & 0.5899 \\
\hline $\mathrm{SC} 2$ & $\begin{array}{l}\text { The open space allows me to know } \\
\text { the surrounding citizens of the area }\end{array}$ & 0.5030 & 0.2840 & 0.0043 & 0.2746 & 0.8914 \\
\hline $\mathrm{SC} 3$ & $\begin{array}{l}\text { The open space strengthen the } \\
\text { relationship between the citizens here }\end{array}$ & 0.0001 & 0.1407 & 0.0026 & 0.2893 & 0.6336 \\
\hline SC4 & I feel safe while using the open space & 0.7244 & 0.4615 & 0.0463 & 0.6015 & 0.6488 \\
\hline SC5 & $\begin{array}{l}\text { I know well other people who are } \\
\text { using the open space }\end{array}$ & 0.6276 & 0.1279 & 0.1622 & 0.0016 & 0.6744 \\
\hline SC6 & $\begin{array}{l}\text { The community here know and fully } \\
\text { utilized the open space }\end{array}$ & 0.3480 & 0.1359 & 0.0979 & 0.1795 & 0.9285 \\
\hline
\end{tabular}


PLANNING MALAYSIA

Journal of the Malaysia Institute of Planners (2018)

\begin{tabular}{|c|c|c|c|c|c|c|}
\hline SC7 & $\begin{array}{l}\text { Overall, I would rate the sense of } \\
\text { community in relation with open } \\
\text { space here as very satisfying. }\end{array}$ & 0.2113 & 0.8285 & 0.0565 & 0.2893 & 0.9424 \\
\hline
\end{tabular}

For the social interaction domain, playfield gave a significant value of 0.0054 compared to the other types of open space. Moreover, the design of the playfield also allows majority of the users to socially interact with their friends. According to Philips (1996), a good design of an open spaces should taking consider the needs of the public in regard to their interactions and activities. Moreover, a good design of open space also should comprise all range of people and linked to their own human need. In this study, the selected playfield functions for football activity. Its significant score in social interaction domain suggests that social interaction may be enhanced through outdoor recreational activities.

As for human-nature interaction, the exploratory survey and behaviour mapping conducted suggest that the human-nature interaction in open space domain can be divided into three, which are contact with nature, aesthetic preference, and recreation and play. Table 4 shows the overall findings on humannature interaction in open spaces.

Table 4: Overall findings on human-nature interaction in open spaces

\begin{tabular}{|c|c|c|c|c|c|c|}
\hline \multicolumn{7}{|c|}{ Contact with Nature Domain } \\
\hline & & $\begin{array}{l}\text { Neighbourhood } \\
\text { park }\end{array}$ & Playfield & $\begin{array}{l}\text { Local } \\
\text { park }\end{array}$ & Playground & $\begin{array}{l}\text { Urban } \\
\text { park }\end{array}$ \\
\hline $\mathrm{CN} 1$ & $\begin{array}{l}\text { The design of the open spaces } \\
\text { allows me to contact with nature }\end{array}$ & 0.0000 & 0.1448 & 0.8420 & 0.0793 & 0.6119 \\
\hline $\mathrm{CN} 2$ & $\begin{array}{l}\text { I like the natural appearance of the } \\
\text { open space }\end{array}$ & 0.0391 & 0.0664 & 0.4124 & 0.0275 & 0.9085 \\
\hline $\mathrm{CN} 3$ & $\begin{array}{l}\text { I feel calm with the nature provided } \\
\text { in the open spaces }\end{array}$ & 0.0025 & 0.1146 & 0.6688 & 0.0000 & 0.8369 \\
\hline $\mathrm{CN} 4$ & $\begin{array}{l}\text { I can pursue many activities with } \\
\text { nature in this open spaces }\end{array}$ & 0.0001 & 0.1413 & 0.8490 & 0.6567 & 0.0768 \\
\hline CN5 & $\begin{array}{l}\text { I can appreciate the nature when } \\
\text { I'm in the open space }\end{array}$ & 0.0023 & 0.0782 & 0.4947 & 0.5010 & 0.1223 \\
\hline CN6 & $\begin{array}{l}\text { Overall, I would rate the nature in } \\
\text { this open space as very satisfying. }\end{array}$ & 0.5867 & 0.6556 & 0.6172 & 0.3070 & 0.3931 \\
\hline \multicolumn{7}{|c|}{ Aesthetic Preference Domain } \\
\hline AP1 & $\begin{array}{l}\text { The open space allows me to value } \\
\text { aesthetic elements }\end{array}$ & 0.1749 & 0.9512 & 0.2187 & 0.8743 & 0.1656 \\
\hline AP2 & $\begin{array}{l}\text { I like the natural preference in this } \\
\text { open space }\end{array}$ & 0.2517 & 0.9646 & 0.0426 & 0.9267 & 0.8080 \\
\hline AP3 & $\begin{array}{l}\text { I feel calm with the aesthetic } \\
\text { elements provided in the open space }\end{array}$ & 0.4123 & 0.6396 & 0.0168 & 0.5228 & 0.5362 \\
\hline AP4 & $\begin{array}{l}\text { I can pursue many activities in } \\
\text { relation with aesthetic element in this } \\
\text { open space }\end{array}$ & 0.8721 & 0.8439 & 0.1468 & 0.6251 & 0.9159 \\
\hline AP5 & $\begin{array}{l}\text { I can appreciate the aesthetic } \\
\text { elements when I'm in the open space }\end{array}$ & 0.0019 & 0.7161 & 0.0441 & 0.6492 & 0.0562 \\
\hline AP6 & $\begin{array}{l}\text { Overall, I would rate the aesthetic } \\
\text { preference in this open space as very } \\
\text { satisfying. }\end{array}$ & 0.4010 & 0.0611 & 0.0152 & 0.5186 & 0.1717 \\
\hline \multicolumn{7}{|c|}{ Recreational and Play Domain } \\
\hline $\mathrm{RP}^{\prime}$ & $\begin{array}{l}\text { The open spaces allows me to have } \\
\text { recreational activities }\end{array}$ & 0.3629 & 0.0031 & 0.0199 & 0.4505 & 0.2513 \\
\hline
\end{tabular}


Filzani Illia Ibrahim, Dasimah Omar \& Nik Hanita Nik Mohamad Multi-Dimensional Human Interaction in Open Spaces

\begin{tabular}{|c|c|c|c|c|c|c|}
\hline RP2 & $\begin{array}{l}\text { The open spaces provides various } \\
\text { activities for recreational purposes }\end{array}$ & 0.6393 & 0.0079 & 0.0005 & 0.9463 & 0.4982 \\
\hline RP3 & $\begin{array}{l}\text { I feel calm when doing recreational } \\
\text { activities here }\end{array}$ & 0.7070 & 0.3338 & 0.0016 & 0.5816 & 0.4377 \\
\hline RP4 & $\begin{array}{l}\text { I can pursue many physical activities } \\
\text { in this open spaces }\end{array}$ & 0.1176 & 0.0136 & 0.0000 & 0.2005 & 0.6688 \\
\hline RP5 & $\begin{array}{l}\text { There are various of facilities } \\
\text { provided in the open spaces for } \\
\text { recreational activities }\end{array}$ & 0.0311 & 0.2663 & 0.0089 & 0.5784 & 0.4008 \\
\hline RP6 & $\begin{array}{l}\text { I normally do recreational activities } \\
\text { here alone }\end{array}$ & 0.0546 & 0.1271 & 0.0053 & 0.4970 & 0.3873 \\
\hline RP7 & $\begin{array}{l}\text { I normally do recreational activities } \\
\text { here with my partner/group }\end{array}$ & 0.7422 & 0.7491 & 0.0054 & 0.7715 & 0.4960 \\
\hline RP8 & $\begin{array}{l}\text { Overall, I would rate the recreational } \\
\text { activities provided in the open space } \\
\text { as very satisfying }\end{array}$ & 0.5120 & 0.9788 & 0.0004 & 0.0207 & 0.3212 \\
\hline
\end{tabular}

For contact with nature domain, neighbourhood park shows the highest significant value in terms of design, natural appearance, sense of calmness, activities provided and sense of nature appreciation. In comparison, playground also shows significant value on natural appearance and sense of calmness. As for the other types of open space, none shows significant value in relation to contact with nature. These are contrasted with the finding by Chiesura (2004) that the vitality of contact with nature is shown to hold across a wide range of urban context which includes greenways and parks. However, open space, through its ability to offer contact with nature, has been found to reduce stress, promote relaxation and restoration, and reduce anger, fear and aggression (Ulrich, Dimberg, \& Driver, 1991). Hence, contact with nature should be considered in the design stage of open space as it not only promotes physical but also mental wellbeing.

As for recreational activities and play domain, the local park shows the most significant value for the domain. In comparison, neighbourhood park, playfield and playground also show significant value towards recreational activity and play domain. This is in tandem with the socio-ecological framework proposed by Sallis (2009) that users of open space would be more physically active if the open space offers an accessible, safe and attractive place for exercise. Moreover, findings by Merom, Tudor-Locke, Bauman and Rissel (2003) suggest that close access to open space does encourage greater use by local people that contributes to greater physical activity. In relation to this study, all types of open spaces, except for Urban Park, were found to successfully provided interaction for the recreational activities. However, in relation to the behaviour mapping analysis, urban park shows among the significant numbers of physical activities in the area. Giles-Corti et al. (2005) argued that attractiveness, size and specific amenities are factors that determine use of public open space, which could be measured to determine the association between physical activity and public space 
access. Hence, specific amenities should be further improved in the urban park to ensure the users satisfaction towards recreational activities at the park.

Table 5 shows the overall findings of regression analysis on the perceived benefits and vitality of open spaces domain. The table shows that the urban park fulfilled both perceived benefits for the human-nature interactions and humanhuman interactions. According to Department and Town and Country Planning Peninsular Malaysia (2013), urban park should function as local attraction for recreational activities and nature appreciation. Hence, this shows that Section 2 urban park positively fulfils the perceived benefits for the users at the open space.

Additionally, Section 8 playing field and Section 7 local park also fulfils the perceived benefits of human-human interactions in the open spaces. This is due to the function of the open spaces whereby the Section 8 functions as playing field. Hence, human interaction occurred highly in the area. The Department of Town and Country Planning (2013) suggested that playfield should cater for three division of neighbourhood which functions as recreational activities for children, teenagers and adults. Local park should cater for local dwellers' recreational, sport and social community needs.

Table 5: Overall findings of perceived benefits and vitality of open space domain

\begin{tabular}{|c|c|c|c|c|c|c|c|c|c|}
\hline \multirow{2}{*}{\multicolumn{2}{|c|}{ Model }} & \multicolumn{2}{|c|}{$\begin{array}{l}\text { Unstandardized } \\
\text { Coefficients }\end{array}$} & \multirow{2}{*}{$\begin{array}{l}\text { Standardized } \\
\text { Coefficients } \\
\text { Beta }\end{array}$} & \multirow[t]{2}{*}{ Sig. } & \multicolumn{3}{|c|}{$\begin{array}{l}\text { Dependent Variable: Perceived } \\
\text { Benefit }\end{array}$} & \multirow[t]{2}{*}{$\begin{array}{l}\text { Overall } \\
\text { Result }\end{array}$} \\
\hline & & $\mathrm{B}$ & $\begin{array}{l}\text { Std. } \\
\text { Error }\end{array}$ & & & $\mathrm{R}$-square & F-statistics & $\begin{array}{l}\mathrm{p}- \\
\text { value }\end{array}$ & \\
\hline \multicolumn{10}{|c|}{ Section 18} \\
\hline \multirow[t]{3}{*}{1} & (Constant) & 2.685 & .334 & & .000 & 0.059 & 4.004 & 0.021 & \\
\hline & Human-nature & .148 & .075 & .172 & .051 & & & & $\mathrm{X}$ \\
\hline & Human-human & .106 & .065 & .142 & .108 & & & & $\mathrm{X}$ \\
\hline \multicolumn{10}{|c|}{ Section 8} \\
\hline \multirow[t]{3}{*}{1} & (Constant) & 2.162 & .426 & & .000 & 0.18 & 10.444 & 0 & \\
\hline & Human-nature & .044 & .091 & .045 & .634 & & & & $\mathrm{X}$ \\
\hline & Human-human & .360 & .083 & .412 & .000 & & & & $\sqrt{ }$ \\
\hline \multicolumn{10}{|c|}{ Section 7} \\
\hline \multirow[t]{3}{*}{1} & (Constant) & 1.572 & 467 & & .001 & 0.206 & 15.685 & 0 & \\
\hline & Human-nature & .064 & .129 & .049 & .619 & & & & $\mathrm{X}$ \\
\hline & Human-human & .558 & .130 & .424 & .000 & & & & $\sqrt{ }$ \\
\hline \multicolumn{10}{|c|}{ Section 4} \\
\hline \multirow[t]{3}{*}{1} & (Constant) & 3.240 & .473 & & .000 & 0.04 & 0.927 & 0.403 & \\
\hline & Human-nature & .105 & .105 & .159 & .321 & & & & $\mathrm{X}$ \\
\hline & Human-human & .054 & .117 & .073 & .650 & & & & $\mathrm{X}$ \\
\hline \multicolumn{10}{|c|}{ Section 2} \\
\hline \multirow[t]{3}{*}{1} & (Constant) & 1.262 & .221 & & .000 & 0.301 & 56.474 & 0.000 & \\
\hline & Human-nature & .418 & .065 & .383 & .000 & & & & $\sqrt{ }$ \\
\hline & Human-human & .222 & .054 & .246 & .000 & & & & $\sqrt{ }$ \\
\hline
\end{tabular}

\section{CONCLUSION}

In conclusion, this study has shown that open space is vital to city sustainability. Provision of open space must consider human interaction domain in order to ensure the benefits of open space reach the users of open space. Elements of open 
Filzani Illia Ibrahim, Dasimah Omar \& Nik Hanita Nik Mohamad

Multi-Dimensional Human Interaction in Open Spaces

space such as green space, water features and physical attributes need to be included in its design in order to enhance the interactions between human-human and human-nature in open space.

\section{ACKNOWLEDGEMENT}

The authors would like to thank all officers of Taylors University and Research Management Institute of Universiti Teknologi MARA for their support in conducting this study.

\section{REFERENCES}

Arifin, H. S. (2005). Pemeliharaan taman (edisi revisi). Jakarta: Penebar Swadaya.

Chiesura, A. (2004). The role of urban parks for the sustainable city. Landscape and Urban Planning, 68(1), 129-138.

Conway, H. (2000). Parks and people: the social functions. In J. Woudstra, K, Fieldhouse (Eds.), The regeneration of public parks (pp. 9-20). London: E\&FN Spon.

Department of Town and Country Planning of Peninsular Malaysia (2013). Planning guidelines of open spaces and recreation areas. Kuala Lumpur: Ministry of Housing and Local Government.

Giles-Corti, B., Sallis, J. F., Sugiyama, T., Frank, L. D., Lowe, M., \& Owen, N. (2015). Translating active living research into policy and practice: One important pathway to chronic disease prevention. Journal of Public Health Policy, 36, 231243.

Kaplan, R., (1993). The role of nature in the context of the workplace. Landscape and Urban Planning, 26(1-4), 193-201.

Kim, S. (2015, March 30). Public spaces - not a "nice to have" but a basic need for cities. Retrieved from http:// http://blogs.worldbank.org/endpovertyinsouthasia/public-spaces-not-nice-havebasic-need-cities

Mansor, M., Said, I., \& Mohamad, I. (2010). Experiental contacts with green infrastructure's diversity and well being of urban community. Asian Journal of Environment-Behaviour Studies, 31-47.

Marzukhi, M. A., Karim, H. A., \& Latfi, M. F. (2012). Evaluating the Shah Alam City Council policy and guidelines on the hierarchy of neighborhood open space. Procedia - Social and Behavioral Sciences, 36, 456-465.

Matsuoka, R. H., \& Kaplan, R. (2008). People needs in the urban landscape : Analysis of landscape and urban planning contributions. Landscape and Urban Planning, 84(1), 7-19.

Merom, D., Tudor-Locke, C., Bauman, A., \& Rissel, C. (2006). Active commuting to school among NSW primary school children: Implications for public health. Health and Place 12(4), 678-687.

Mutiara, S., \& Isami, K. (2012). Characteristic of public small park usage in Asia Pacific countries: Case study in Jakarta and Yokohama City, Procedia - Social and Behavioral Sciences, 35, 412-419. 
PLANNING MALAYSIA

Journal of the Malaysia Institute of Planners (2018)

Oguz, D. (2000). User surveys of Ankara's urban parks. Landscape and Urban Planning, 52(2-3), 165-171.

Philips, L. E. (1996). Parks: Design and management. New York: McGrawHill.

Sallis, J. F. (2009). Measuring physical activity environments: A brief history. American Journal of Preventive Medicine, 36, S86-S92.

Sekaran, U., \& Bougie, R. (2016). Research methods for business: A skill-building approach. Chichester, West Sussex, United Kingdom: John Wiley \& Sons.

Ulrich, R. S., Dimberg, V., \& Driver, B. L. (1991). Psychophysiological indicators of leisure benefits. In B. L. Driver, P. J. Brown, \& G. L. Peterson, (Eds.), Benefits of leisure. (n.p.): Venture Publication. 